\title{
Reviving the architectural heritage values of Al-Aqmar Mosque as an archi- tectural inherited and a source of inspiration for contemporary interior design
}

\author{
RadwaMohamed Salah El Din ${ }^{1,}$ Prof. Dr. Ola Ali Hashim ${ }^{2}$, Prof. Dr. Ashraf Hussein ${ }^{3}$
}

1) Demonstratorin the Department of Decoration and Interior Architecture - the Higher Institute of Applied Arts - 6th of October

2) Professor of Design, Department of Interior Design and Furniture - Faculty of Applied Arts - Helwan University

3) Professor of Design, Department of Interior Design and Furniture - Faculty of Applied Arts - Helwan University

\section{KEY WORDS:}

Keywords: architectural inherited, authenticity, architectural elements, entrances, muqarnas, decades, architectural values.

\begin{abstract}
:
The study examines the architecture of Al-Aqmar Mosque because of its great importance in the Fatimid architectural inheritedand the conclusion of the most important architectural values influencing its construction and rooting those values through monitoring and analysis of some architectural elements and items through analytical studies provided by this mosque to show the extent of its impact on its design and how the mosque became a source of heritage inspiration of the mosques of the following eras, with different parts of the design in the content and formulation according to the impact of the same era, and models of each type of following eras were selected for the Aqmar Mosque to confirm this, and how the security and wealth of the state affected the luxury of Fatimid architecture, The study also indicates how the material, texture, color, shade and light affect the architectural product and architectural treatments in the architectural formation.
\end{abstract}

\section{INTRODUCTION:}

Caliph Al AmrBeahkam Allah ordered the establishment of the Al-Aqmar Mosque and his minister, al-Ma'mun al-Bataahi, supervised its construction that was completed (519 AH- 1125 AD). Fatimid architecture flourished in Egypt thanks to security, state wealth and religious tolerance and openness to cultures. It is considered one of the most beautiful Fatimid mosques and has several advantages: It is considered the first facade decorated in the Egyptian mosques, and through the analysis of this facade we find that the first phenomenon of decoration in the facade of the Al-Aqmar Mosque is the oyster radiation that emerges from the center that represents the sun, and the use of niche hanging from the top of the mihr$a b$ in the façade. It is also the first decorative example of its kind in the architecture of Cairo and even in the whole Islamic architecture, in addition to the facade contains a variety of ornaments that make it a unique masterpiece in the architecture of Cairo in the Fatimid era, and is also noted the first use of muqarnas as an element of Islamic decoration, as low-mounted domes appeared on spherical triangles and here have evolved to cover the corridors in the mosques in Egypt, and all of those features made Al- Aqmar mosque has historic value and dimension.

\section{RESEARCH PROBLEM:}

the lack of intellectual link between the legacy and methods of application in contemporary interior design, ie we see that contemporary design has become a metaphor only formal without depth in the meaning of architectural formation.

\section{Research hypothesis:}

The architectural design of Al- Aqmar Mosque is a source of heritage inspiration for the mosques of eras that follow it with some differences in both material and design according to the impact of the same era. 


\section{Main objectives of the research are:}

- To extract new relationships and lines of design that serve the interior design in line with the spirit of the times and at the same time do not lose identity and maintain authenticity through the architectural and symbolic analysis of some architectural elements of Al Aqmar mosque, and access to this analysis for the intellectual link between the legacy and contemporaneity as an applied axis of design.

- Borrow concepts and items of traditional architecture in a modern and innovative way and integrate it into contemporary concepts and items.

The research follows: the historical and descriptive analytical approach.

\subsection{The concept of revival:}

Revival is a concept of the process of intellectual link between heritage and contemporaneity, which is the re-use of heritage deliverables at the cultural and civilizational level. Architectural revival means the complete or partial recovery of ancient symbols, concepts, ideas and solutions.

There is no doubt that this requires a deep understanding of the roots of architectural thought represented in the architecturalinherited, which still retains its heritage characteristics as a source of architectural formations and formulations, and these roots are the overall result of culture, civilization and the spirit of the times with natural influences, meaning that the peoples who aim to revive the ancient heritage must still maintain a large part of the elements of civilization in which this heritage originated, and the process of revival of heritage depends on two basic and consecutive steps: reading and inspiring the values of heritage, and then revive heritage values inspired and integrate them into the architectural framework or contemporary interior design.

\subsection{Architectural inherited:}

Architectural inheritedrefers to the sum of buildings that have continued and proved their authenticity and value against continuous change. The architectural inheritedstands out as a reference and a governing framework, comprising "visual and canvases constants" that can inspire, guide and influence the architect in his search for "optimal formulas" to shape the environment and architectural production.

\subsection{Authenticity:}

Authenticity means homogeneity in time and communication with thelegacy, and that the present is a con- tinuation of its past, and its future as a continuation of its present. Authenticity does not mean self-conflagration, rejection of others, and alienation of the stranger as a fake intruder and intrusion in which the self-identity is lost, Authenticity in this sense is isolation.

Islamicinherited experienced authenticity and achieved it when it was contemporary, that is, when it had an awareness of itself, time and history. With a contemporary word when it was modern in its time, this is the essence of modernity, creating authenticity and not bringing it from anywhere, because the inherent is the first and last version of itself, and not from something else, so it was important to understand the concept of communication.

\subsection{Concept of communication:}

Communication is the interdependence of all time in the past, for it, interdependence does not mean conformity, but means developing it, preserving its spirit and supporting it with modern methods and the latest science and arts techniques. Heritage is not something for transport, but for the addition, development, growth and modernization and linking it with the future, as linked to the past, and perhaps the most important thing when studying the culture of a society is the study of the values contained in that culture, no doubt that culture is a link to the past with the present and the future through shared and continuous and evolving values between them.

In order to preserve the principle of personality development rather than reproduction, it is necessary to find the language of intellectual communication between the architectural inheritedand contemporary designs and apply it in designs that reflect the intellectual connection between heritage and contemporaneity. 
Table (1) shows the analysis of the horizontal projection of Al Aqmar mosque:

\begin{tabular}{|c|c|c|}
\hline Description and analysis & Symbolic analysis & Illustrations \\
\hline $\begin{array}{l}\text { Architectural Description: } \\
\text { The mosque consists of a cen- } \\
\text { tral open courtyard square with } \\
\text { a small area and is surrounded } \\
\text { by four corridors, the largest of } \\
\text { which is the qibla hallway. In } \\
\text { mosques in the Ottoman era. } \\
\text { The concept of alignment of the } \\
\text { building of the street first ap- } \\
\text { peared in Al Aqmar Mosque, } \\
\text { where the mosque is directly di- } \\
\text { rected to the qibla and is aligned } \\
\text { with the facade facing the street. } \\
\text { The broken entrance area faces } \\
\text { the west to allow the facade to } \\
\text { align with the street. This tenden- } \\
\text { cy to modify the position of the } \\
\text { qibla in order to level the ranks } \\
\text { of worshipers when praying and } \\
\text { thus became the Qibla in the cor- } \\
\text { rect position inside the mosque } \\
\text { deviated for its facade, and this } \\
\text { architectural element appeared } \\
\text { for the first time in Al Aqmar } \\
\text { mosque. It was taken by most } \\
\text { mosques and mosques that have } \\
\text { been exposed to the phenomenon } \\
\text { of Qiblah tendency in the Islam- } \\
\text { ic world and Egypt, where Egypt } \\
\text { is deviated from the direction of } \\
\text { the Kaaba and the qibla in Egypt } \\
\text { year southeast in the direction of } \\
\text { the Kaaba. } \\
\text { - Hence we conclude how the } \\
\text { shape of the building was in- } \\
\text { fluenced by religion and belief, } \\
\text { which created a hallmark of this } \\
\text { era. }\end{array}$ & $\begin{array}{l}\text { Symbolism emerged from the } \\
\text { falls of to be free in two direc- } \\
\text { tions, one horizontal level link- } \\
\text { ing it to the place of the Kaaba } \\
\text { and the other vertical upward to } \\
\text { the sky appears through the dome } \\
\text { and minarets and balconies, and } \\
\text { thus symbolize the absolute and } \\
\text { interdependence between the } \\
\text { earth and the sky. } \\
\text { Wrapping value: The laws of } \\
\text { substance are the small wraps } \\
\text { around the large; the electron in } \\
\text { the atom revolves around the nu- } \\
\text { cleus, the moon around the earth, } \\
\text { the earth around the sun, the sun } \\
\text { around the galaxy, and the gal- } \\
\text { axy around a larger galaxy. The } \\
\text { circumnavigation of the Kaaba } \\
\text { is one of the rituals of Muslims } \\
\text { in Hajj and Umrah. Where the } \\
\text { Almighty says: (and (again) cir- } \\
\text { cumambulate the Ancient House) } \\
\text { (verse 29) of Surat Al-Hajj, and } \\
\text { the idea of roaming does not only } \\
\text { exist in the world, but also found } \\
\text { in the Hereafter at Paradise and } \\
\text { Hell, in Paradise the Almighty } \\
\text { says (And round about them } \\
\text { will (serve) youths of perpetual } \\
\text { (freshess) \{Verse } 17 \text { \} of Surat } \\
\text { Al Waqea, in hell, the Almighty } \\
\text { says: "They will go around be- } \\
\text { tween it and scalding water, heat- } \\
\text { ed [to the utmost degree]" (verse } \\
44 \text { ) of Al-Rahman. } \\
\text { - Hence we conclude that the } \\
\text { idea of circumambulation and } \\
\text { convolution comes from the na- } \\
\text { ture developed by the Creator } \\
\text { where used by the Muslim archi- } \\
\text { tect to reach the previous mean- } \\
\text { ings, and note this here through } \\
\text { the open courtyard, which wraps } \\
\text { around all the components of the } \\
\text { mosque. }\end{array}$ & $\begin{array}{l}\text { Figure (1) Horizontal projector of Al } \\
\text { Aqmar Mosque "Quoting from the Cen- } \\
\text { ter for Registration of Islamic and Coptic } \\
\text { Antiquities in the Citadel" }\end{array}$ \\
\hline
\end{tabular}


Table (2) shows the analysis of some architectural elements of Al Aqmar Mosque:

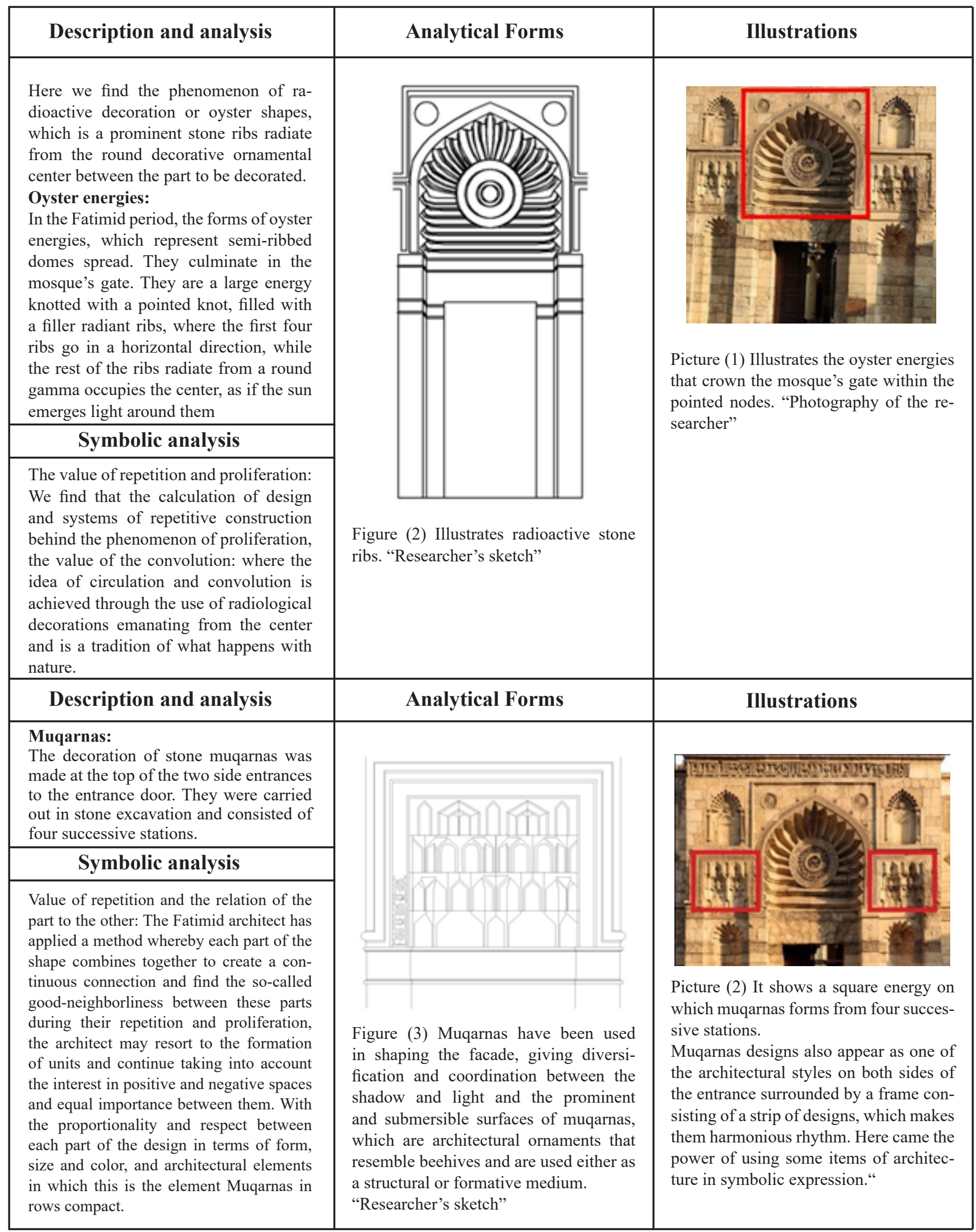


Table (3) shows the analysis of some architectural elements of Al Aqmar mosque:

\begin{tabular}{|c|c|c|}
\hline Description and analysis & Analytical Forms & Illustrations \\
\hline $\begin{array}{l}\text { Stucco windows "Sunshades": } \\
\text { Above the walls are a number of simi- } \\
\text { lar decorative windows. Each window is } \\
\text { crowned by a pointed arch and is defined } \\
\text { from the outside by a band of plant mo- } \\
\text { tifs. The inside of the window is filled } \\
\text { with an ornament in the form of a mihr- } \\
\text { ab, and the interior of the mihrab is filled } \\
\text { with geometric motifs. Accuracy of its } \\
\text { decoration, shadow and light resulting } \\
\text { from the spaces resulting from the de- } \\
\text { sign parts. }\end{array}$ & 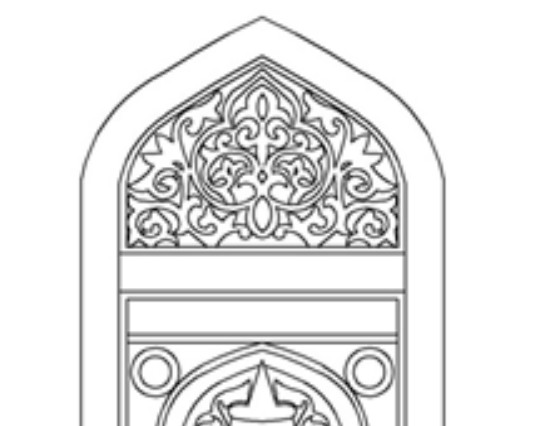 & \\
\hline Symbolic analysis & & \\
\hline $\begin{array}{l}\text { The openings are linked to the element } \\
\text { of light, which is one of the four intellec- } \\
\text { tual constants affecting the philosophi- } \\
\text { cal thought of the Muslim architect. } \\
\text { The connection of light to the sky and } \\
\text { the earth had its causal relation to the } \\
\text { rise of these openings above the human } \\
\text { level, and they refer to the connection to } \\
\text { the infinite universe through sight, and } \\
\text { to the connection of the building to the } \\
\text { universe and the orientation of its com- } \\
\text { ponents towards the sky }\end{array}$ & $\begin{array}{l}\text { Figure (4) Illustrates plaster nets. "Re- } \\
\text { searcher's sketch" }\end{array}$ & $\begin{array}{l}\text { Picture (3) The stucco nets at the top of } \\
\text { the mosque's wall show the accuracy of } \\
\text { the industry and the beauty of the design. } \\
\text { It was based on the work of many nar- } \\
\text { row architectural openings covered with } \\
\text { stucco windows to reduce the intensity } \\
\text { of light, and help control the journey of } \\
\text { light from outside the building inside. } \\
\text { "Photography of the researcher" }\end{array}$ \\
\hline Description and analysis & Analytical Forms & Illustrations \\
\hline $\begin{array}{l}\text { Inscriptions: Kufic calligraphy was used } \\
\text { as a main element of the decorative com- } \\
\text { position: The arches of the mosque's } \\
\text { façade are engraved with stucco inscrip- } \\
\text { tions engraved with Qur'anic verses in } \\
\text { kufic script. In spite of its simplicity, we } \\
\text { find the Muslim artist combining the arts } \\
\text { of writing and engaging with the dec- } \\
\text { orations around him in the form of the } \\
\text { most creative images of writings in the } \\
\text { Fatimid era. }\end{array}$ & \multirow{3}{*}{$\begin{array}{l}\text { Figure (5) A detailed section illustrates } \\
\text { the use of Kufic script in writing Qur'an- } \\
\text { ic verses that circumvent the arches of } \\
\text { the eastern façade overlooking the court- } \\
\text { yard, and the text of its verses: "Allah is } \\
\text { the Light of the heavens and the earth. } \\
\text { The Parable of His Light is as if there } \\
\text { were a Niche and within it a Lamp: the } \\
\text { Lamp enclosed in Glass: "Researcher's } \\
\text { sketch }\end{array}$} & \multirow[b]{3}{*}{$\begin{array}{l}\text { Picture (4) It shows part of the bar of the } \\
\text { Qur'anic verses that wraps around the } \\
\text { arches of the facades of the courtyard. } \\
\text { which made writing in this part of the } \\
\text { mosque performed its functional role in } \\
\text { addition to its aesthetic value itself. } \\
\text { "Photography of the researche }\end{array}$} \\
\hline Symbolic analysis & & \\
\hline $\begin{array}{l}\text { The letters with twigs have taken on the } \\
\text { appearance of unity and integration, which } \\
\text { enriched the aesthetic value, and the princi- } \\
\text { ple of monotheism had the greatest impact } \\
\text { on the architectural decorations represent- } \\
\text { ed in the biblical tapes, which are infinite } \\
\text { Qur'anic verses that cannot be distin- } \\
\text { guished from its end, and the use of Kufic } \\
\text { script in writing Qur'anic verses. Wrapping } \\
\text { around the facades of the courtyard facing } \\
\text { the eye of the chapel to permeate his soul } \\
\text { and prepare him psychologically to appear } \\
\text { in the hands of God. }\end{array}$ & & \\
\hline
\end{tabular}


Table (4) shows the effect of formative values on the interface of Al Aqmar Mosque:

\begin{tabular}{|c|c|c|c|}
\hline Color & Shadow and light & Surface contact & Rhythm \\
\hline $\begin{array}{l}\text { Natural stone color was } \\
\text { used in facades, which is } \\
\text { considered one of the ba- } \\
\text { sic colors used in Islamic } \\
\text { art without introducing } \\
\text { any artificial colors on } \\
\text { it. This also made it last } \\
\text { without changing its fea- } \\
\text { tures from what it was at } \\
\text { the time of its creation, } \\
\text { so as to adapt that raw } \\
\text { material to the environ- } \\
\text { ment of the place where } \\
\text { the mosque so as not to } \\
\text { appear strange with the } \\
\text { place where it was cre- } \\
\text { ated. } \\
\text { The use of natural stone } \\
\text { material highlighted the } \\
\text { color of the material. }\end{array}$ & $\begin{array}{l}\text { The artist used shadow } \\
\text { and light to show the de- } \\
\text { sign levels in the facade. } \\
\text { It also relied on shadow } \\
\text { and light just no materi- } \\
\text { al difference to show the } \\
\text { functionality and aesthet- } \\
\text { ics of the interface. } \\
\text { In the vast majority of the } \\
\text { facade wall parts, which } \\
\text { were of aesthetic value, } \\
\text { he used a prominent and } \\
\text { deep stone engraving } \\
\text { technique. }\end{array}$ & $\begin{array}{l}\text { The surface of the facade } \\
\text { gained richness in the } \\
\text { touches of its surfaces } \\
\text { by changing the ways of } \\
\text { its decoration and wall } \\
\text { cladding from the use } \\
\text { of clamshell energies at } \\
\text { once, muqarnas at once, } \\
\text { and pediments at other } \\
\text { times. } \\
\text { This fascinating blend } \\
\text { created a kind of richness } \\
\text { to the surface of the fa- } \\
\text { cade, as it is the address } \\
\text { of the place. }\end{array}$ & $\begin{array}{l}\text { In the facade, the artist } \\
\text { relied on the repeated } \\
\text { rhythm and symme- } \\
\text { try achieved by the use } \\
\text { of the oyster energies, } \\
\text { muqarnas, and sym- } \\
\text { metrical shortcomings } \\
\text { around the axis of the } \\
\text { door. Those elements } \\
\text { that gave a sense of rota- } \\
\text { tion around the center of } \\
\text { the facade, then came the } \\
\text { role of plant decoration } \\
\text { strips used by the artist at } \\
\text { the top of the facade and } \\
\text { bands of decorative mo- } \\
\text { tifs above the entrance } \\
\text { and the top of the facade } \\
\text { in the transverse direc- } \\
\text { tion to give a stop in the } \\
\text { rhythm and then make a } \\
\text { repeated rhythm again, to } \\
\text { give a balanced rhythm } \\
\text { for the facade as a whole }\end{array}$ \\
\hline
\end{tabular}

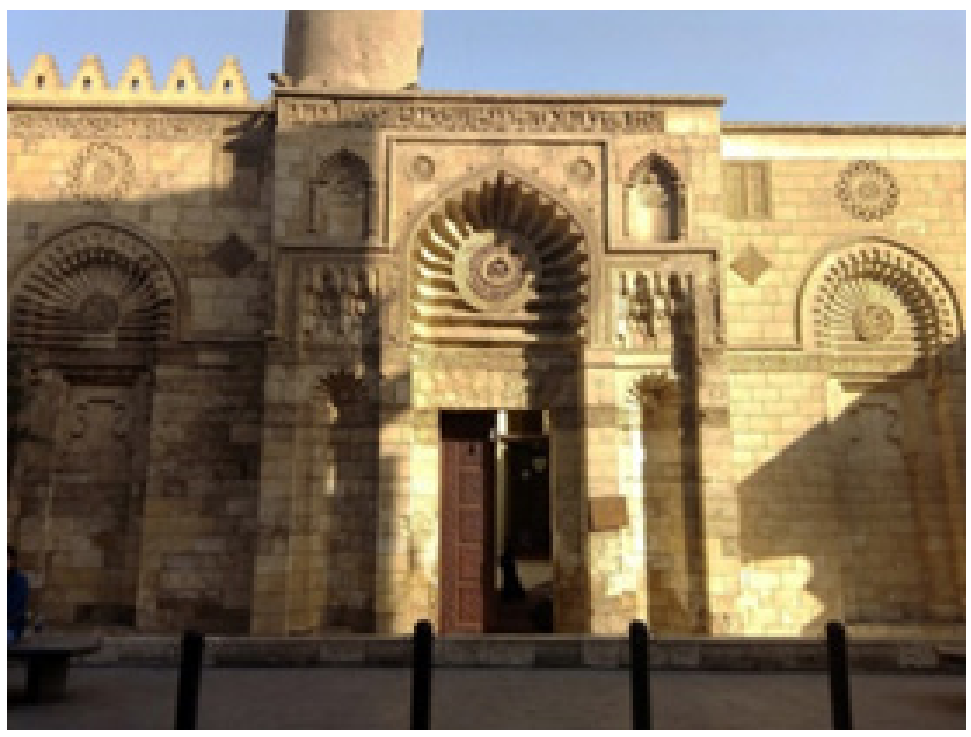

picture (5) Illustrates the facade of Al Aqmar Mosque "Quoting Web Sites" 
Table (5) shows the impact of some heritage values on Al-Aqmar Mosque:

\begin{tabular}{|c|c|}
\hline Heritage value & Influence \\
\hline $\begin{array}{l}\text { 1-The value of } \\
\text { social conceal- } \\
\text { ment }\end{array}$ & $\begin{array}{l}\text { Figure (6) The horizontal projection of Al Aqmar } \\
\text { Mosque is determined by the partiality of the broken } \\
\text { entrance } \\
\text { - The value of social concealment in Al-Aqmar } \\
\text { Mosque is achieved through the design of the broken } \\
\text { entrance. It covers the blanks of the mosque from } \\
\text { the passers-by on the road and its façade at the same } \\
\text { time adjacent to the street, besides his main function } \\
\text { is to address the tendency of the Qibla. }\end{array}$ \\
\hline $\begin{array}{l}\text { 2- Value of } \\
\text { privacy }\end{array}$ & $\begin{array}{l}\text { picture (6) Shows the dome above the prayer house } \\
\text {-The value of privacy in Al-Aqmar Mosque is } \\
\text { achieved through the general formation of the } \\
\text { mosque's spaces where it is characterized by the in- } \\
\text { tegration between the spaces and the dynamic link } \\
\text { between them, and to confirm the variation through } \\
\text { the sudden transition from the narrow, twisted vac- } \\
\text { uum of the broken entrance to the large vacuum } \\
\text { leading to the courtyard, and also through the closed } \\
\text { parts such as the dome above the house of prayer. }\end{array}$ \\
\hline $\begin{array}{l}\text { 3- The value of } \\
\text { credibility and } \\
\text { openness in ex- } \\
\text { pression }\end{array}$ & $\begin{array}{l}\text { The interlock cymbals above the entrance door illus- } \\
\text { trate the pinched rinse on the facade } \\
\text { The value of credibility and frankness in the ex- } \\
\text { pression in Al Aqmar Mosque through the architec- } \\
\text { tural expression of the structural elements is clearly } \\
\text { achieved through the thresholds for the openings } \\
\text { "cymbals" and rinse rinsing, and the non-use of } \\
\text { whiteness to cover the materials used in the con- }\end{array}$ \\
\hline
\end{tabular}


Table (6) shows the impact of some heritage values on Al-Aqmar Mosque:

\begin{tabular}{|c|c|}
\hline Heritage value & Influence \\
\hline $\begin{array}{l}\text { 4- The value of } \\
\text { spirituality }\end{array}$ & $\begin{array}{l}\text { The courtyard of the al-Aqmar mosque illus- } \\
\text { trates a portion of the verse of the Qur'anic } \\
\text { verses that wraps around the arches of the } \\
\text { courtyard facades. } \\
\text { Mosque achieved through the architect's in- } \\
\text { terest in preserving the spiritual side, and the } \\
\text { use of architectural elements of architectural }\end{array}$ \\
\hline $\begin{array}{l}\text { 5- The value of } \\
\text { openness }\end{array}$ & $\begin{array}{l}\text { picture (11)picture (12) } \\
\text { the entrance of Al Aqmar Mosquethe entrance } \\
\text { of the mosque of Mahdia } \\
\text { influenced by the entrance of the Mahdiain- } \\
\text { fluenced by Ancient Roman architecture } \\
\text {-The value of openness is realized through the } \\
\text { influence of Fatimid architecture by Syrian } \\
\text { and Byzantine art, which confirms the open- } \\
\text { ness of Islamic architecture to other cultures }\end{array}$ \\
\hline
\end{tabular}


Table (6) shows how Al Aqmar Mosque became a source of heritage inspiration for the ensuing mosques, with different parts of the design in the content and formulation according to the effect of the same period:

\begin{tabular}{|c|c|}
\hline Al Aqmar Mosque (Fatimid era) & Dome of Al SalehNajm al-Din Ayyub (Ayyubid era) \\
\hline $\begin{array}{l}\text {-This muqarnas is the first example of its kind in the } \\
\text { religious buildings of Cairo. These stone muqarnas } \\
\text { are an evolution of the idea of the muqarnas, which } \\
\text { was used in the Fatimid domes in both the domes of } \\
\text { al-Hakim Mosque and the dome of Mashhad al-Jiushi } \\
\text { and both of al-Ja'fari and SayyidaAtika domes. This } \\
\text { muqarnas was divided into successive monolithic } \\
\text { decorative elements that resulted in this muqarnas } \\
\text { chest we see crowned up the two entries indicated. }\end{array}$ & $\begin{array}{l}\text { Theevolution of the use of muqarnas in the Ayyu- } \\
\text { bid era is evident from the figure referred to in the } \\
\text { dome of Al SalehNajm al-Din, illustrated how Aqmar } \\
\text { Mosque has become a source of inspiration heritage } \\
\text { to use the cornice with the difference in the use of ra- } \\
\text { tios and diversity in the use of raw Part of the plaster } \\
\text { and part used as suns decorated with stained glass, } \\
\text { and the use of the interior design but in Al Aqmar } \\
\text { mosque was used in the external facade. }\end{array}$ \\
\hline Al Aqmar Mosque (Fatimid era) & Sultan Qalawun Collection (Mamluk Era) \\
\hline $\begin{array}{l}\text { The study of the façade of Al Aqmar Mosque be- } \\
\text { gan by giving it some architectural touches to avoid } \\
\text { the boredom caused by the lack of diversification in } \\
\text { the form of the wall, especially large areas where the } \\
\text { pediments were used to express the introduction of } \\
\text { the third dimension and the introduction of a sense of } \\
\text { space, although the composition is still face. }\end{array}$ & $\begin{array}{l}\text { Picture (16) Illustrates the pediments of the Sultan } \\
\text { Qalawun Mosque "Photography of the researcher" } \\
\text { is evidenced by the picture referred to in the Sultan } \\
\text { Qalawun Mosque, and it is clear how the mosque be- } \\
\text { came a source of heritage inspiration for the use of } \\
\text { pediments with the difference in the use of propor- } \\
\text { tions and diversity in the use of material, as the ped- } \\
\text { iment itself is of marble and background of mosaic. }\end{array}$ \\
\hline
\end{tabular}




\section{Results:}

1- Al-Aqmar Mosque is the first study of the facades in the Fatimid era. It was the beginning of the use of muqarnas, pediments and domes on the corridors and for the first time using the broken entrance in the Islamic mosques in Cairo, it is an important source of inspiration for the mosques of the following eras.

2- Fatimid architecture with an architectural thought that is inseparable from the human and the environment, and therefore it can benefit from this thought in the interior design because it is not thought associated with a specific time or certain elements, but has been linked to fixed principles and values.

3- The importance of reflecting the heritage of culture and its inspiration in the interior design to represent the sincere expression of intellectual identity and originality.

4- Methods of intellectual link between heritage and contemporary through two main objectives: revival, communication, and the existence of communication is linked to the existence of logic, which must develop heritage.

\section{Recommendations:}

1- Maximizing the role of Egyptian Islamic monuments and their impact on the tourist attraction, through publicity and advertisement of the Fatimid architectural inherited and taking care of it.

2- Promoting awareness and thought regarding the values of the architectural inheritedderived from the Al-Aqmar Mosque and linking it with the interior design of materials that are environmentally friendly and also suitable for function and use.

\section{References:}

(1) Ahmed Abdel Aziz Amin, Aesthetic and Functional Values of Interior Design of Sultan Hassan Mosque and its Application to Reception Areas in Major Hotels, MA, Department of Interior Design and Furniture, Faculty of Applied Arts (2000).

(2) Sami Abdullah Mohammed, Interior Architecture of AlAqmar Mosque, MA, Department of Decoration and Interior Architecture, Faculty of Fine Arts (1993).

(3) Ola Ali Hashim, Balancing Heritage and Contemporary Values for the Design of Tourism Facilities of Islamic Architectural Character, First International Conference on Urban Heritage in Islamic Countries.

(4) Kamal Mahmoud Kamal El Gabalawy, Symbolic Ideas in Egyptian Architecture After the Entry of Islam, Publisher Dar Al-Fikr Al-Arabi (2009).
(5) Mohamed Ahmed Mahmoud Ahmed, Architectural Inheritedand its Impact on Contemporary Egyptian Architecture, MA, Department of Architecture, Faculty of Engineering (2008).

(6) Mohamed Abdel Fattah Ahmed Ismail, Architectural Formation between Heritage and Contemporary Values Towards an Intellectual Approach to Communication Logic, MA, Department of Architecture, Faculty of Engineering (2000). 